\title{
THE THERMAL DECOMPOSITION OF POTASSIUM AND SODIUM-PYROSULFATE
}

\author{
K. J. DE VRIES and P. J. GELLINGS \\ Twente, University of Technology, Enschede, The Netherlands \\ (First Received 16 August 1967; in revised form 20 September 1968)
}

\begin{abstract}
Proceeding from $\mathrm{KHSO}_{4}, \mathrm{~K}_{2} \mathrm{~S}_{2} \mathrm{O}_{8}, \mathrm{NaHSO}_{4}$ and $\mathrm{Na}_{2} \mathrm{~S}_{2} \mathrm{O}_{8}$, potassium- and sodium-pyrosulfates were prepared and their thermal decomposition was investigated by a T.G.A. method. This was done in order to clarify contradictory values found in the literature. The presence of an intermediate with composition $\mathrm{K}_{2} \mathrm{SO}_{5}$ was detected.
\end{abstract}

\section{INTRODUCTION}

IN A RECENT literature survey we found a wide variety of data on the decomposition temperatures of dry, powdered potassium- and sodium-pyrosulfates. The starting materials used by different investigators were either freshly prepared pyrosulfates or pyrosulfates obtained from the thermal decomposition of the corresponding dry, powdered hydro- and peroxydi-sulfates. Table 1 lists the values found. The thermal decomposition reactions are considered to be:

$$
\begin{aligned}
& 2 \mathrm{KHSO}_{4} \rightarrow \mathrm{K}_{2} \mathrm{~S}_{2} \mathrm{O}_{7}+\mathrm{H}_{2} \mathrm{O} \\
& \mathrm{K}_{2} \mathrm{~S}_{2} \mathrm{O}_{8} \rightarrow \mathrm{K}_{2} \mathrm{~S}_{2} \mathrm{O}_{7}+\frac{1}{2} \mathrm{O}_{2} \\
& \mathrm{~K}_{2} \mathrm{~S}_{2} \mathrm{O}_{7} \rightarrow \mathrm{K}_{2} \mathrm{SO}_{4}+\mathrm{SO}_{3} \\
& \mathrm{NaHSO}_{4} \cdot \mathrm{H}_{2} \mathrm{O} \rightarrow \mathrm{NaHSO}_{4}+\mathrm{H}_{2} \mathrm{O} \\
& 2 \mathrm{NaHSO}_{4} \rightarrow \mathrm{Na}_{2} \mathrm{~S}_{2} \mathrm{O}_{7}+\mathrm{H}_{2} \mathrm{O} \\
& \mathrm{Na}_{2} \mathrm{~S}_{2} \mathrm{O}_{8} \rightarrow \mathrm{Na}_{2} \mathrm{~S}_{2} \mathrm{O}_{7}+\frac{1}{2} \mathrm{O}_{2} \\
& \mathrm{Na}_{2} \mathrm{~S}_{2} \mathrm{O}_{7} \rightarrow \mathrm{Na}_{2} \mathrm{SO}_{4}+\mathrm{SO}_{3}
\end{aligned}
$$

In order to clarify the contradictory literature values we re-investigated the decomposition ranges of the reactions (3) and (7) between $20-1000^{\circ} \mathrm{C}$ using the corresponding hydro-, peroxydi- and pyrosulfates as starting materials.

\section{EXPERIMENTAL}

The compounds used were analytical grade: $\mathrm{KHSO}_{4}\left(\mathrm{E}\right.$. Merck), $\mathrm{K}_{2} \mathrm{~S}_{2} \mathrm{O}_{8}$ (E. Merck), $\mathrm{K}_{2} \mathrm{~S}_{2} \mathrm{O}_{7}$ (Brocades-Stheeman), $\mathrm{NaHSO}_{4} \cdot \mathrm{H}_{2} \mathrm{O}$ (E. Merck), $\mathrm{Na}_{2} \mathrm{~S}_{2} \mathrm{O}_{8}$ (Riedel-De Haën).

The samples were powdered and dried by heating at $56^{\circ} \mathrm{C}$ in air for about $72 \mathrm{hr}$. This was immediately followed by the thermogravimetric analyses (T.G.A.) between 20 and $1000^{\circ} \mathrm{C}$.

These analyses were carried out in a Stanton TR-01 thermobalance in an atmosphere of air. Samples of about $100 \mathrm{mg}$ of the pre-dried compounds were placed in glazed alumina crucibles preheated in air to $500^{\circ} \mathrm{C}$ for a day. No buoyancy corrections were applied. Heating rates used were $2 / 3^{\circ}, 4 / 3^{\circ}$ and $4^{\circ} \mathrm{C} / \mathrm{min}$. The decomposition products were quenched by simply removing the furnace of the Stanton TR-01. Their composition was checked by analytical methods. No evidence was found that a reaction of the products with $\mathrm{CO}_{2}$ of atmospheric air had taken place.

From the diffraction patterns formed in a Guinier II camera (Nonius) using $\mathrm{Cu} \mathrm{K} \alpha$ radiation we obtained $d$ values of the decomposition products. These values were corrected using $\mathrm{AlNH}_{4}\left(\mathrm{SO}_{4}\right)_{2}$. $12 \mathrm{H}_{2} \mathrm{O}$ as a standard and were compared with the A.S.T.M. X-ray data file. 
Table 1. Thermal decomposition data of potassium- and sodium-pyrosulfate into the corresponding normal sulfates proceeding from the hydro-, peroxydi- and pyrosulfates respectively as found in the literature

\begin{tabular}{|c|c|c|c|c|c|}
\hline \multirow{2}{*}{$\begin{array}{l}\text { Authors } \\
\text { Spitsyn, } \\
\text { Meerov }\end{array}$} & \multirow{2}{*}{$\frac{\text { Reference }}{[1]}$} & \multirow{2}{*}{$\begin{array}{l}\begin{array}{l}\text { Starting } \\
\text { material }\end{array} \\
\mathrm{KHSO}_{4}\end{array}$} & \multicolumn{2}{|c|}{$\begin{array}{l}\text { Reactions } \\
\text { involved }\end{array}$} & \multirow{2}{*}{$\begin{array}{c}\begin{array}{c}\text { Decomposition data* for } \\
\text { reactions (3) and (7) respec- } \\
\text { tively }\end{array} \\
\text { sets in between } 370-420^{\circ} \mathrm{C}\end{array}$} \\
\hline & & & (1) & (3) & \\
\hline $\begin{array}{l}\text { Tomkova, Jiru, } \\
\text { Rozicky }\end{array}$ & [2] & $\mathrm{KHSO}_{4}$ & (1) & (3) & $\begin{array}{l}\text { occurs between } 395 \text { and about } \\
800^{\circ} \mathrm{C} \dagger\end{array}$ \\
\hline $\begin{array}{l}\text { Wendtlandt, } \\
\text { Sturm }\end{array}$ & [3] & $\mathrm{KHSO}_{4}$ & (1) & (3) & occurs between 470 and $700^{\circ} \mathrm{C}$ \\
\hline Duval & [4] & $\mathrm{K}_{2} \mathrm{~S}_{2} \mathrm{O}_{8}$ & (2) & (3) & $\begin{array}{l}\text { occurs between } 488 \text { and about } \\
900^{\circ} \mathrm{C}\end{array}$ \\
\hline Wickert & [5] & $\mathrm{K}_{2} \mathrm{~S}_{2} \mathrm{O}_{7}$ & & (3) & occurs between 321 and $800^{\circ} \mathrm{C}$ \\
\hline Duval & [6] & $\mathrm{K}_{2} \mathrm{~S}_{2} \mathrm{O}_{7}$ & & (3) & $\begin{array}{l}\text { starts progressively above } \\
210^{\circ} \mathrm{C} \text { and is completed around } \\
870^{\circ} \mathrm{C} \ddagger \text {; heating rate used } \\
5^{\circ} \mathrm{C} / \mathrm{min}\end{array}$ \\
\hline $\begin{array}{l}\text { Spitsyn, } \\
\text { Meerov }\end{array}$ & [1] & $\mathrm{NaHSO}_{4}$ & (5) & (7) & sets in between $320-370^{\circ} \mathrm{C}$ \\
\hline Duval & [7] & $\mathrm{NaHSO}_{4}$ & (5) & (7) & $\begin{array}{l}\text { occurs between } 430 \text { and } 620^{\circ} \mathrm{C} \text {; } \\
\text { heating rates used are between } \\
2.5 \text { and } 5^{\circ} \mathrm{C} / \mathrm{min}\end{array}$ \\
\hline $\begin{array}{l}\text { Tomkova, Jiru, } \\
\text { Rozicky }\end{array}$ & [2] & $\mathrm{NaHSO}_{4}$ & (4) (5) & (7) & occurs between 370 and $780^{\circ} \mathrm{C} \dagger$ \\
\hline $\begin{array}{l}\text { Boros, } \\
\text { Lorant }\end{array}$ & [8] & $\mathrm{NaHSO}_{4}$ & (5) & (7) & finishes at $910^{\circ} \mathrm{C}$ \\
\hline Duval & [4] & $\mathrm{Na}_{2} \mathrm{~S}_{2} \mathrm{O}_{7}$ & & (7) & occurs between 197 and $800^{\circ} \mathrm{C}$ \\
\hline
\end{tabular}

*achieved by various Thermogravimetric Analyses (T.G.A.).

t the authors used steady and increasing temp. methods.

$\ddagger$ the author's T.G.A. curve flattens near $680^{\circ} \mathrm{C}$.

\section{RESULTS}

The Figs. 1, 2 and 3 show the T.G.A. curves, obtained at two heating rates, for potassium hydro-, peroxydi- and pyrosulfate.

The Figs. 4 and 5 show the comparable T.G.A. curves for $\mathrm{NaHSO}_{4}$ and $\mathrm{Na}_{2} \mathrm{~S}_{2} \mathrm{O}_{8}$ respectively. The parts of the curves between $\mathrm{Na}_{2} \mathrm{~S}_{2} \mathrm{O}_{7}$ and $\mathrm{Na}_{2} \mathrm{SO}_{4}$ were not reproducible.

The Tables 2 and 3 show the observed data for the conversion of potassiumand sodium-pyrosulfates into the normal sulfates.

1. V. I. Spitsyn and M. A. Meerov,J. Gen. Chem. USSR. 22963 (1952).

2. D. Tomkova, P. Jiru and J. Rozicky, Colln Czech. chem. Commun. 25957 (1960).

3. W. W. Wendtlandt and E. Sturm, J. inorg. nucl. Chem. 25, 535 (1963).

4. C. Duval, Analytica chim. Acta. 20, 20 (1959).

5. K. Wickert, Brennst-Wärme-Kraft. 11, 110 (1959).

6. C. Duval, Microchim. Ichnoanal. Acta 348 (1963).

7. C. Duval, Inorganic Thermogravimetric Analyses. Elsevier, Amsterdam pp. 198, 257, 258 (1963).

8. M. Boros and B. Lorant, Seifen-Öle-Fette-Wachse. 89, 531, 555 (1963). 


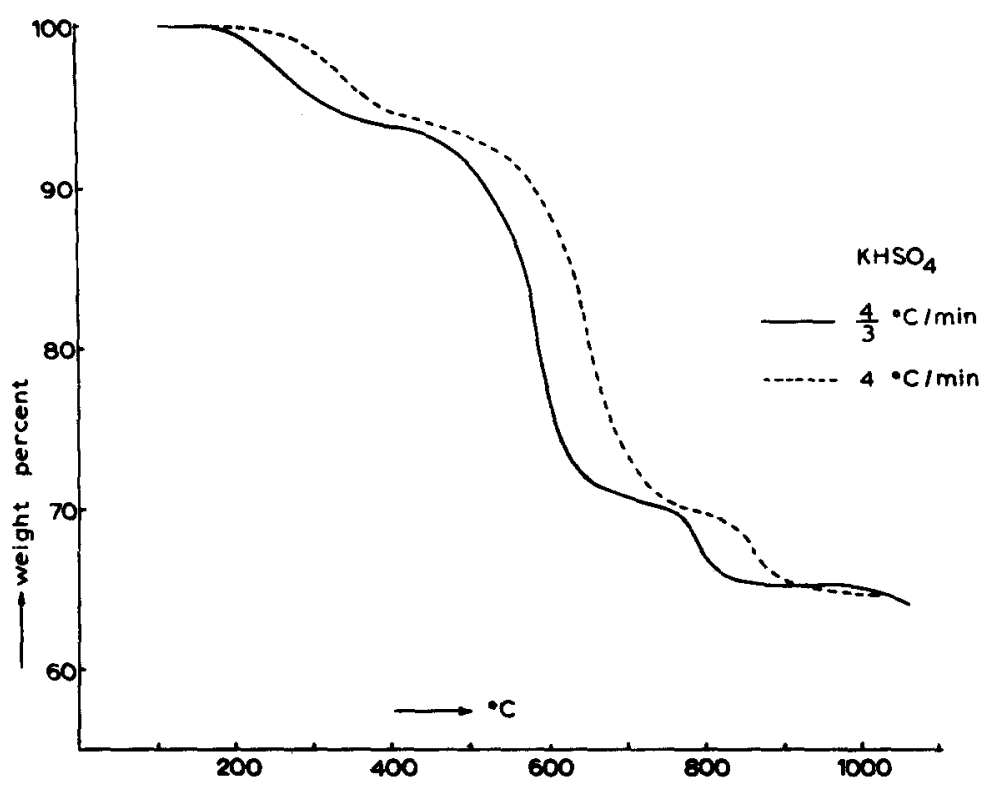

Fig. 1. T.G.A. curves of $\mathrm{KHSO}_{4}$ between 20 and $1000^{\circ} \mathrm{C}$ taken at different heating rates.

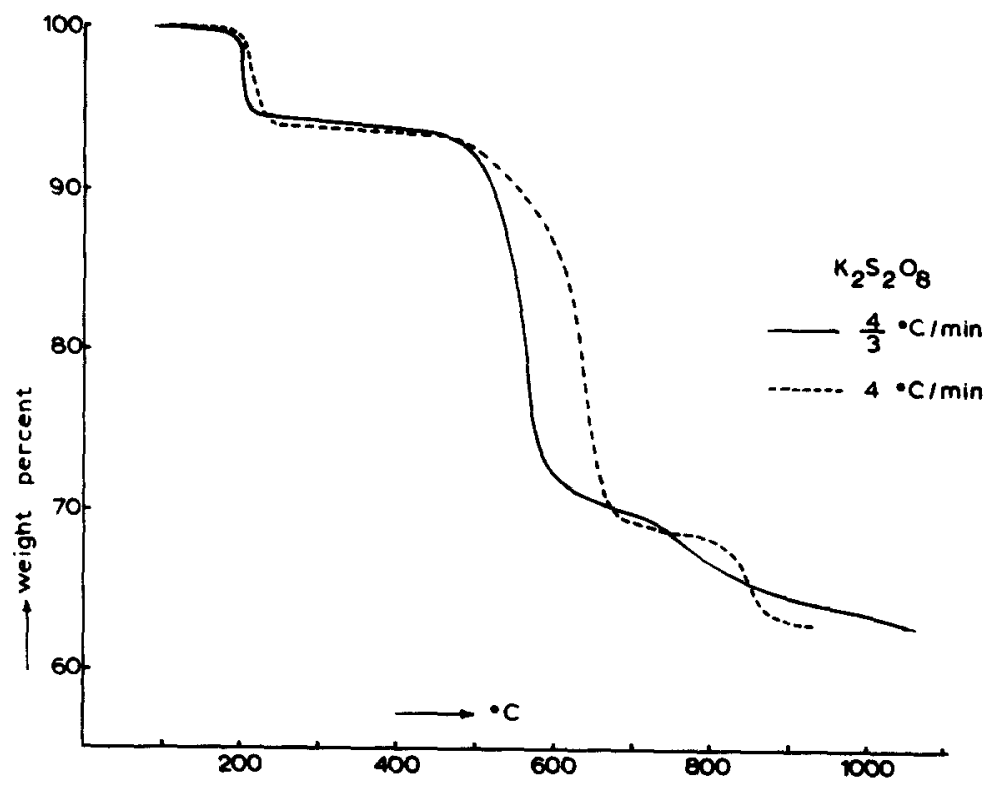

Fig. 2. T.G.A. curves of $\mathrm{K}_{2} \mathrm{~S}_{2} \mathrm{O}_{8}$ between 20 and $1000^{\circ} \mathrm{C}$ taken at different heating rates. 


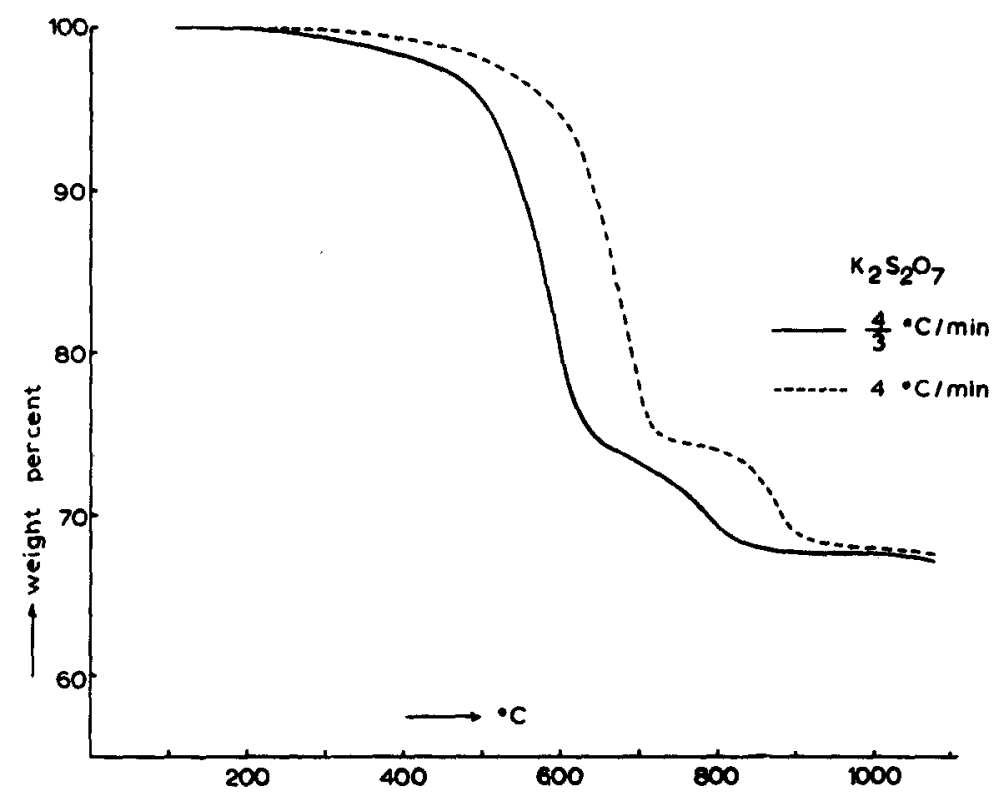

Fig. 3. T.G.A. curves of $\mathrm{K}_{2} \mathrm{~S}_{2} \mathrm{O}_{7}$ between 20 and $1000^{\circ} \mathrm{C}$ taken at different heating rates.

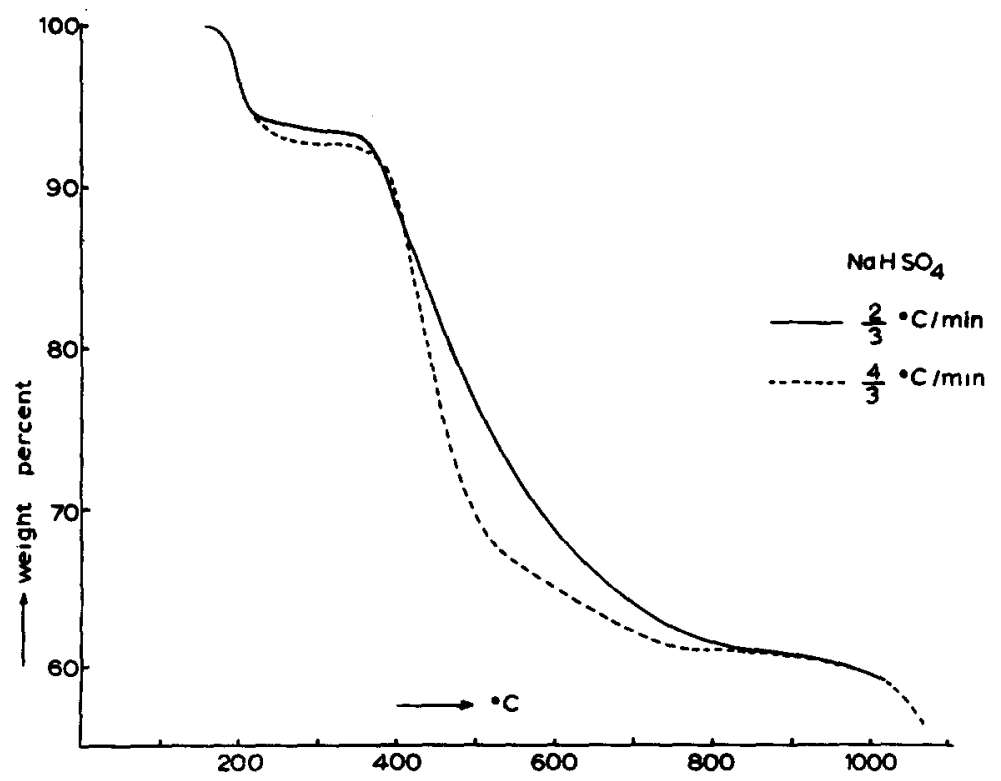

Fig. 4. T.G.A. curves of $\mathrm{NaHSO}_{4}$ between 20 and $1000^{\circ} \mathrm{C}$ taken at different heating rates. 


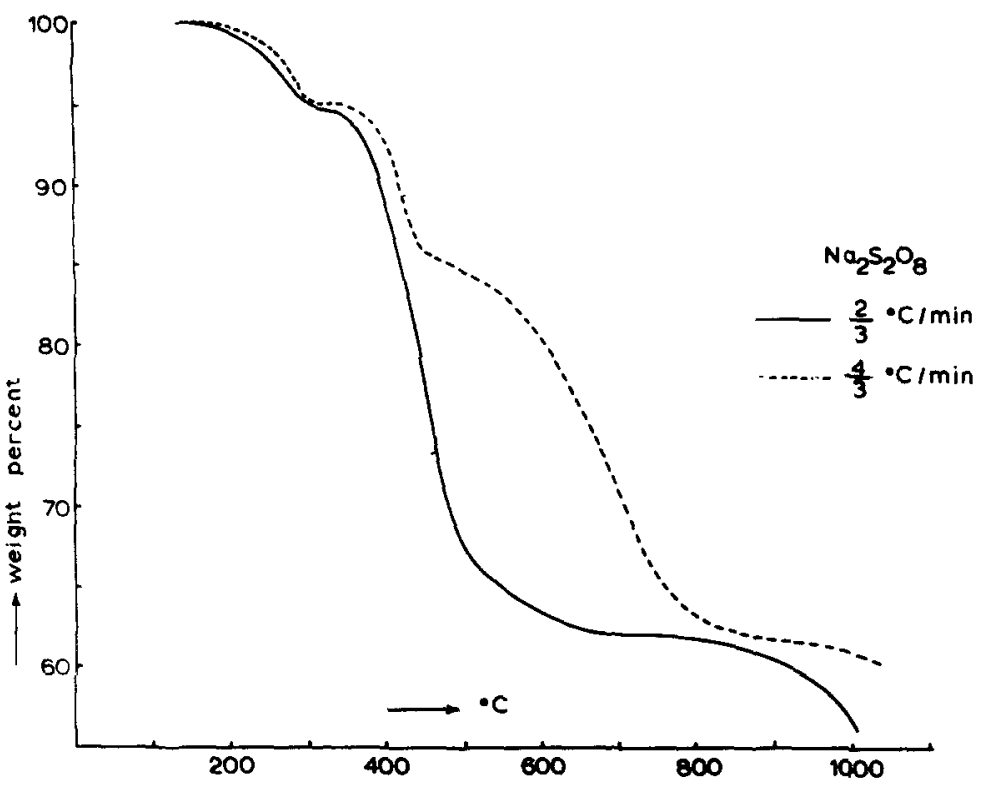

Fig. 5. T.G.A. curves of $\mathrm{Na}_{2} \mathrm{~S}_{2} \mathrm{O}_{8}$ between 20 and $1000^{\circ} \mathrm{C}$ taken at different heating rates.

Table 2. Thermal decomposition ranges of the various potassium pyrosulfates into normal potassium sulfate

\begin{tabular}{lccc}
\hline & & Heating rate $4 / 3^{\circ} \mathrm{C} / \mathrm{min}$ & Heating rate $4{ }^{\circ} \mathrm{C} / \mathrm{min}$ \\
\cline { 3 - 4 } $\begin{array}{c}\text { Starting } \\
\text { material }\end{array}$ & Reaction & $\begin{array}{c}\text { Decomposition range } \\
\left({ }^{\circ} \mathrm{C}\right)\end{array}$ & $\begin{array}{c}\text { Decomposition range } \\
\left({ }^{\circ} \mathrm{C}\right)\end{array}$ \\
\hline $\mathrm{KHSO}_{4}$ & $(3)$ & $390-650$ & $400-700$ \\
& & $650-840$ & $700-920$ \\
$\mathrm{~K}_{2} \mathrm{~S}_{2} \mathrm{O}_{8}$ & $(3)$ & $400-650$ & $400-690$ \\
$\mathrm{~K}_{2} \mathrm{~S}_{2} \mathrm{O}_{7}$ & $(3)$ & $650-840$ & $690-900$ \\
& & $400-650$ & $400-710$ \\
& & $650-840$ & $710-910$ \\
\hline
\end{tabular}

Table 3. Thermal decomposition ranges of sodium-pyrosulfate obtained from $\mathrm{NaHSO}_{4}$ and $\mathrm{Na}_{2} \mathrm{~S}_{2} \mathrm{O}_{3}$

\begin{tabular}{lcccc} 
& $\begin{array}{c}\text { Heating rate } \\
2 / 3^{\circ} \mathrm{C} / \mathrm{min}\end{array}$ & $\begin{array}{c}\text { Heating rate } \\
4 / 3^{\circ} \mathrm{C} / \mathrm{min}\end{array}$ & $\begin{array}{c}\text { Heating rate } \\
4{ }^{\circ} \mathrm{C} / \mathrm{min}\end{array}$ \\
\cline { 2 - 5 } $\begin{array}{c}\text { Starting } \\
\text { material }\end{array}$ & Reaction & $\begin{array}{c}\text { Decomposition } \\
\text { range } \\
\left({ }^{\circ} \mathrm{C}\right)\end{array}$ & $\begin{array}{c}\text { Decomposition } \\
\text { range } \\
\left({ }^{\circ} \mathrm{C}\right)\end{array}$ & $\begin{array}{c}\text { Decomposition } \\
\text { range } \\
\left({ }^{\circ} \mathrm{C}\right)\end{array}$ \\
\hline $\mathrm{NaHSO}_{4}$ & $(7)$ & $330-820$ & $340-850$ & $390-900$ \\
$\mathrm{Na}_{2} \mathrm{~S}_{2} \mathrm{O}_{8}$ & $(7)$ & $330-800$ & $340-830$ & $370-900$ \\
\hline
\end{tabular}


We found that in all the T.G.A. curves of the various potassium pyrosulfates there was a knee just dividing the decomposition (3) into two parts which correspond with the following reaction scheme:

$$
\begin{gathered}
\mathrm{K}_{2} \mathrm{~S}_{2} \mathrm{O}_{7} \rightarrow \mathrm{K}_{2} \mathrm{SO}_{5}+\mathrm{SO}_{2} \\
\mathrm{~K}_{2} \mathrm{SO}_{5} \rightarrow \mathrm{K}_{2} \mathrm{SO}_{4}+\frac{1}{2} \mathrm{O}_{2} .
\end{gathered}
$$

In order to find whether the intermediate step could be connected with a separate phase the reaction was stopped at the temperature where the intermediate step appeared. The diffraction pattern of this product was compared with the diffraction patterns of the neighbouring phases $\mathrm{K}_{2} \mathrm{~S}_{2} \mathrm{O}_{7}$ and $\mathrm{K}_{2} \mathrm{SO}_{4}$. Both these latter phases were detected but there were more diffraction lines present in the diffraction pattern of the intermediate and these were ascribed to belong to " $\mathrm{K}_{2} \mathrm{SO}_{5}$ ".

In Table 4 we have listed the $d$ values found from the diffraction pattern of the intermediate in the first column. The $d$ values of $\mathrm{K}_{2} \mathrm{~S}_{2} \mathrm{O}_{7}$ and $\mathrm{K}_{2} \mathrm{SO}_{4}$ as taken

Table 4

\begin{tabular}{cccc}
\hline $\begin{array}{c}\text { Powder pattern } \\
d \\
(\AA)\end{array}$ & $\begin{array}{c}\text { A.S.T.M. } \\
\mathrm{K}_{2} \mathrm{~S}_{2} \mathrm{O}_{7} \\
(\AA)\end{array}$ & $\begin{array}{c}\text { A.S.T.M. } \\
\mathrm{K}_{2} \mathrm{SO}_{4} \\
(\AA)\end{array}$ & $\begin{array}{c}\text { " } \mathrm{K}_{2} \mathrm{SO}_{5} " \\
(\AA)\end{array}$ \\
\hline 3.93 & & 3.93 & \\
3.85 & 3.85 & & 3.69 \\
3.69 & & & \\
3.65 & 3.65 & & 3.20 \\
3.40 & 3.40 & & 3.15 \\
3.20 & & & \\
3.15 & & & \\
3.09 & 3.09 & \\
3.07 & 3.07 & & \\
2.12 & & & \\
2.11 & & & \\
2.10 & & & \\
1.76 & 1.76 & & \\
1.72 & & & \\
1.69 & & & \\
\hline
\end{tabular}

from the A.S.T.M index and coinciding with the $d$ values found by us for these materials, are given in the next two columns. In the last column of Table 4 the remaining $d$ values are listed which were assumed to be due to the intermediate $\mathrm{K}_{2} \mathrm{SO}_{5}$.

\section{DISCUSSION}

From the weight losses taken from the T.G.A. curves, the X-ray diffraction patterns and chemical analyses we may conclude that the thermal decomposition of the potassium-and sodium-, hydro-, peroxydi- and pyrosulfates occurs in definite steps which agree with the reaction scheme given by the reactions (1)-(7). Comparing the decomposition data listed in Tables 1,2 and 3 with each other we 
can match, within the limits given in Tables 2 and 3, the thermal decomposition data mentioned in the literature with exception of reaction (3) proceeding from $\mathrm{K}_{2} \mathrm{~S}_{2} \mathrm{O}_{7}$ for which Wickert [5] and Duval[6] gave lower values for the initiating temperature.

From Tables 2 and 3 we find that for the same heating rate the decomposition ranges of potassium pyrosulfates of different origin hardly differ. The behaviour of the sodium pyrosulfates is similar.

From the results using different heating rates, it appears that both the initial decomposition temperature and the decomposition range at which the pyrosulfates convert into the sulfates depend upon the heating rates used. Considering the complete conversion, (see Figs. 1-5), from the starting material to the normal sulfate it is noticed that the higher the heating rate the less sharp the intermediate step in the T.G.A. curve. Hence the variation in decomposition data found in the literature, (see Table 1), can be well explained to be due to different heating rates and procedures while such parameters as crystallite size and specific surface are as yet not considered.

We found that in the T.G.A. curves of the potassium sulfates of various origins a clear intermediate step appeared at which the observed loss in weight agreed exactly with the calculated loss of $\mathrm{SO}_{2}$. The evolution of $\mathrm{SO}_{2}$ was proved qualitatively by an iodometric analysis procedure. The weight loss from the intermediate step towards $\mathrm{K}_{2} \mathrm{SO}_{4}$ agreed well with the calculated loss of oxygen. The occurence of a flattening in the thermal decomposition curve of $\mathrm{K}_{2} \mathrm{~S}_{2} \mathrm{O}_{7}$ at about $680^{\circ} \mathrm{C}$ as measured by Duval[6] seems to be similar with the one found here.

The existence of a separate phase was established by means of the X-ray diffraction experiment.

In the T.G.A. curves of the sodium sulfates of various origins we could not detect any reproducible flattening of the curve that could be associated with an intermediate stage in the decomposition. Hence it might be concluded that a phase of composition " $\mathrm{Na}_{2} \mathrm{SO}_{5}$ " must be less stable than a phase of composition " $\mathrm{K}_{2} \mathrm{SO}_{5}$ ", a conclusion which might also be expected from a consideration of the stability rules for salts with an easily polarizable anion.

Acknowledgement-The authors are pleased to thank Mr. J. Boeijsma for his help with the X-ray diffraction experiments. 